Article

\title{
Fuel Properties of Torrefied Biomass from Sapindus Pericarp Extraction Residue under a Wide Range of Pyrolysis Conditions
}

\author{
Wen-Tien Tsai ${ }^{1, * \mathbb{D}}$, Tasi-Jung Jiang ${ }^{1}$, Yu-Quan Lin ${ }^{1}$, Xiang Zhang ${ }^{2}$, Kung-Sheng Yeh $^{2}$ and Chi-Hung Tsai ${ }^{3}$ \\ 1 Graduate Institute of Bioresources, National Pingtung University of Science and Technology, Neipu \\ Township, Pingtung 912, Taiwan; joybook528er@gmail.com (T.-J.J.); wsx55222525@gmail.com (Y.-Q.L.) \\ 2 Department of Environmental Science and Technology, National Pingtung University of Science and \\ Technology, Neipu Township, Pingtung 912, Taiwan; squirtship94878@gmail.com (X.Z.); \\ k8912080@gmail.com (K.-S.Y.) \\ 3 Department of Resources Engineering, National Cheng Kung University, Tainan 701, Taiwan; \\ ap29fp@gmail.com \\ * Correspondence: wttsai@mail.npust.edu.tw
}

Citation: Tsai, W.-T.; Jiang, T.-J.; Lin, Y.-Q.; Zhang, X.; Yeh, K.-S.; Tsai, C.-H. Fuel Properties of Torrefied Biomass from Sapindus Pericarp Extraction Residue under a Wide Range of Pyrolysis Conditions. Energies 2021, 14, 7122. https://doi.org/ 10.3390/en14217122

Academic Editor: Lyes Bennamoun

Received: 10 October 2021

Accepted: 26 October 2021

Published: 1 November 2021

Publisher's Note: MDPI stays neutral with regard to jurisdictional claims in published maps and institutional affiliations.

Copyright: () 2021 by the authors. Licensee MDPI, Basel, Switzerland. This article is an open access article distributed under the terms and conditions of the Creative Commons Attribution (CC BY) license (https:// creativecommons.org/licenses/by/ $4.0 /)$.

\begin{abstract}
In this work, a novel biomass, the extraction residue of Sapindus pericarp (SP), was torrefied by using an electronic oven under a wide range of temperature (i.e., 200-320 ${ }^{\circ} \mathrm{C}$ ) and residence times (i.e., 0-60 min). From the results of the thermogravimetric analysis (TGA) of SP, a significant weight loss was observed in the temperature range of $200-400{ }^{\circ} \mathrm{C}$, which can be divided into the decompositions of hemicellulose (major)/lignin (minor) $\left(200-320^{\circ} \mathrm{C}\right.$ ) and cellulose (major)/lignin (minor) (320-400 $\left.{ }^{\circ} \mathrm{C}\right)$. Based on the fuel properties of the feedstock SP and SP-torrefied products, the optimal torrefaction conditions can be found at around $280^{\circ} \mathrm{C}$ for holding $30 \mathrm{~min}$, showing that the calorific value, enhancement factor and energy yield of the torrefied biomass were enhanced to be $28.60 \mathrm{MJ} / \mathrm{kg}, 1.36$ and $82.04 \mathrm{wt} \%$, respectively. Consistently, the values of the calorific value, carbon content and molar carbon/hydrogen $(\mathrm{C} / \mathrm{H})$ ratio indicated an increasing trend at higher torrefaction temperatures and/or longer residence times. The findings showed that some SP-torrefied solids can be grouped into the characteristics of a lignite-like biomass by a van Krevelen diagram for all the SP-torrefied products. However, the SP-torrefied fuels would be particularly susceptible to the problems of slagging and fouling because of the relatively high contents of potassium $(\mathrm{K})$ and calcium (Ca) based on the analytical results of the energy dispersive X-ray spectroscopy (EDS).
\end{abstract}

Keywords: Sapindus pericarp; torrefaction; fuel property; solid fuel; lignite-like biomass

\section{Introduction}

In order to reduce the emissions of greenhouse gases (e.g., carbon dioxide) from the existing fossil fuel plants, biomass has been used either as a solid fuel directly or as a supplement to fossil fuels. However, a major drawback for the biomass is derived from its lower energy density due to the moisture and noncarbon elements (i.e., hydrogen and oxygen) involved [1]. In addition, biomass is liable to absorb moisture (i.e., hygroscopic nature) even when it has been dried, thus causing a difficult extended storage and increasing the potential for fungus development. Among the lignocellulosic constituents (i.e., cellulose, hemicellulose and lignin) in biomass, the hemicellulose constituent has the highest moisture absorption capacity [2]. In this regard, a pretreatment process, also known as torrefaction, was extensively studied to produce a torrefied biomass for further use in the energy, metallurgical and chemical fields instead of direct use in its original form [3-9]. To maximize the energy density and mass yield of biomass by reducing the contents of noncarbon elements, the typical temperature range for the torrefaction process is between $200{ }^{\circ} \mathrm{C}$ and $300^{\circ} \mathrm{C}$ [1], where hemicellulose can be thermally decomposed but cellulose and lignin will be partly repolymerized or degraded to some extent. 
In Taiwan, soapberry (Sapindus mukorossi) is famous for its industrial use as a natural surfactant (i.e., saponins), which is present in pericarp. Apart from its traditional use in personal cleaning products like detergents and shampoos, the pharmacological and biological actions of this medicinal plant have been recently exploited in the fields of medicine [10-12] and herbicides $[13,14]$. This biosurfactant was also employed for emulsion-based products in food like beverages $[15,16]$. Due to the increase in the industrial and pharmaceutical applications of saponins, various extraction methods have been developed for maximizing the yield without changing its nature. Inevitably, the soapberry pericarp residue after the extraction will be generated in soapberry-based manufacturing plants. In Taiwan, these biomass residues are often treated by incineration and/or landfills. From a circular economy perspective, the reuse of the residual soapberry pericarp as a precursor for producing carbon-rich materials (e.g., biochar) or fuels may be a promising route for carbon sequestration in the mitigation of greenhouse gas emissions.

In view of the thermochemical conversion of residual soapberry pericarp, there is very limited literature on biochar production [17,18]. Zhang et al. [17] studied the oxidative torrefaction at 250 and $300{ }^{\circ} \mathrm{C}$ for holding 10-30 min under oxygen concentrations of $0-21 \%$, showing that the oxygen concentration in the carrier gas had a substantial impact on the mass yield; element (i.e., carbon, hydrogen and nitrogen) contents and calorific value of the biochar produced. In the research by Velusamy et al. [18], they produced biochar from soapberry pericarp at $450{ }^{\circ} \mathrm{C}$ for about $2 \mathrm{~h}$ under the heating rate of $3^{\circ} \mathrm{C} / \mathrm{min}$, which was used as an adsorbent in determining the adsorption performance of antibiotic ciprofloxacin (one of emerging contaminants) in an aqueous solution. However, the specific surface area and total pore volume of the resulting biochar were only $2.22 \mathrm{~m}^{2} / \mathrm{g}$ and $0.016 \mathrm{~cm}^{3} / \mathrm{g}$, respectively.

In the present study, the main aim was to upgrade the fuel properties of a Sapindus pericarp (SP) extraction residue by torrefaction pretreatment under a matrix design of the temperature (i.e., 200, 240, 280 and $320^{\circ} \mathrm{C}$ ) and residence time (i.e., 0, 30 and $60 \mathrm{~min}$ ). Using the data on the calorific value and elemental composition, the fuel properties of SP and its torrefied products were obtained by using instruments such as an adiabatic calorimeter, elemental analyzer (EA) and energy dispersive X-ray spectroscopy (EDS). In addition, the energy yield and enhancement factor for these torrefied products were further calculated to correlate them with the process parameters for finding the optimal torrefaction conditions.

\section{Materials and Methods}

\subsection{Materials}

The starting feedstock SP was collected from a soapberry-based manufacturing factory in Tainan City, Taiwan. The SP sample was shredded by a knife machine and then sieved to particle sizes in the range of $0.841-1.700 \mathrm{~mm}$ (i.e., passed by the opening of mesh No. 12 and retained by the opening of mesh No. 20). In order to remove the moisture and other attached lights, the prepared SP biomass was first dried by an air-circulating oven (about $105^{\circ} \mathrm{C}$ ) overnight (about $12 \mathrm{~h}$ ) before the thermochemical property analyses and the torrefaction experiments.

\subsection{Thermochemical Properties of Soapberry Pericarp Extraction Residue}

In this work, the thermochemical properties of the feedstock SP, including the proximate analysis, ultimate (elemental) analysis, calorific value, thermogravimetric analysis (TGA) and energy-dispersive X-ray spectroscopy (EDS), were first determined as the baseline data on the performance evaluation of the torrefaction. The operations and procedures for these thermochemical analyses have been reported in previous reports [19-21]. Herein, the TGA tests of the feedstock SP (about $200 \mathrm{mg}$ ) were performed under a nitrogen flow of $50 \mathrm{~cm}^{3} / \mathrm{min}$, where the system temperature was increased from room temperature (about $30{ }^{\circ} \mathrm{C}$ ) to $900{ }^{\circ} \mathrm{C}$ under the heating rates of 5 and $10{ }^{\circ} \mathrm{C} / \mathrm{min}$. 


\subsection{Torrefaction Experiments}

It is well-known that the temperature and residence time were the most important process parameters in the torrefaction experiments [1]. In the present study, the preparation of the torrefied products from SP was performed at $200-320{ }^{\circ} \mathrm{C}$ (an interval of $40^{\circ} \mathrm{C}$ ) for holding 0-60 $\mathrm{min}$ (by an interval of $30 \mathrm{~min}$ ) using an electric furnace with a heating rate of about $7{ }^{\circ} \mathrm{C} / \mathrm{min}[20,21]$. Herein, the internal dimensions of the electric oven $(\mathrm{L} \times \mathrm{W} \times \mathrm{H})$ were $64 \times 44 \times 20 \mathrm{~cm}$ and could be operable up to $400{ }^{\circ} \mathrm{C}$. For each experiment, the SP sample (about $1 \mathrm{~g}$ ) was placed on a ceramic crucible, which was equipped with a fitting cover to provide an oxygen-limited environment during the torrefaction. Herein, the torrefaction conditions at $200^{\circ} \mathrm{C}$ and 0 min meant that the torrefied product (i.e., T-SP-200-0) was removed from the furnace promptly when the torrefaction temperature $\left(200^{\circ} \mathrm{C}\right)$ was approached. The mass yield of the SP-torrefied product $\left(\mathrm{MY}_{\mathrm{SP}}\right)$ was calculated by the ratio of its mass $\left(\mathrm{W}_{\mathrm{T}-\mathrm{SP}}\right)$ to the mass of $\mathrm{SP}$ fed $\left(\mathrm{W}_{\mathrm{SP}}\right)$. Furthermore, the enhancement factor $\left(\mathrm{EF}_{\mathrm{T}-\mathrm{SP}}\right)$ and energy yield ( $\left.\mathrm{EY}_{\mathrm{T}-\mathrm{SP}}\right)$ were calculated as follows:

$$
\begin{aligned}
\mathrm{EF}_{\mathrm{T}-\mathrm{SP}} & =\mathrm{CV}_{\mathrm{T}-\mathrm{SP}} / \mathrm{CV}_{\mathrm{SP}} \\
\mathrm{EY}_{\mathrm{T}-\mathrm{SP}} & =\mathrm{MY}_{\mathrm{T}-\mathrm{SP}} \times \mathrm{EF}_{\mathrm{T}-\mathrm{SP}}
\end{aligned}
$$

where $\mathrm{CV}_{\mathrm{T}-\mathrm{SP}}$ and $\mathrm{CV}_{\mathrm{SP}}$ denoted the calorific values of the torrefied product (T-SP) and the feedstock SP, respectively. It should be noted that the torrefaction experiments for the specified temperature and residence time were carried out in duplicate to calculate their means and standard deviations for the uncertainty analysis.

\subsection{Analysis of Fuel Properties}

The fuel properties of the feedstock SP and torrefied product (T-SP), including the calorific value (higher heating value) and elemental contents, were determined by the adiabatic calorimeter (CALORIMETER ASSY 6200; Parr Co., Moline, IL, USA) and an elemental analyzer (vario EL III; Elementar Co., Langenselbold, Germany), respectively. In order to characterize the textural structures and elemental compositions on the surfaces of the SP-based samples, scanning electron microscopy (S-3000N; Hitachi Co., Tokyo, Japan) with energy dispersive X-ray spectroscopy (EDS) (7021-H; HORIBA Co., Kyoto, Japan) were used by applying an accelerating potential of $15.0 \mathrm{kV}$. Prior to the EDS analysis, an ion sputter (E1010; Hitachi Co., Tokyo, Japan) was used to coat a gold film onto the nonconductive surfaces of the target samples.

\section{Results}

\subsection{Thermochemical Characteristics of Soapberry Pericarp (SP) Extraction Residue}

Table 1 shows the data on the thermochemical properties of the dried soapberry pericarp (SP) extraction residue, including the proximate analysis, ultimate (elemental) analysis and calorific value. The figures listed in Table 1 are very close to those reported by Zhang et al. [17]. For example, the calorific value determined by this work was $20.97 \pm 1.89 \mathrm{MJ} / \mathrm{kg}$ in comparison with that $(20.93 \mathrm{MJ} / \mathrm{kg})$ by Zhang et al. [17]. However, the ash content (i.e., $1.62 \mathrm{wt} \%$ ) was lower than those in the literature $[17,22]$. By contrast, the dried SP had a relatively lower ash content than those of crop husk residues, in the range of $1.41-20.26 \%$ (dry basis) [23]. The high calorific value (about $21 \mathrm{MJ} / \mathrm{kg}$ ) should be attributed to its low ash content and high values of volatile matter and fixed carbon. Although the dried SP may be used as a solid biomass fuel, the emissions of the nitrogen oxides (NOx) and sulfur oxides (SOx) will be potentially serious because of its contents of nitrogen $(0.36 \mathrm{wt} \%)$ and sulfur $(0.11 \mathrm{wt} \%)$. 
Table 1. Thermochemical properties of the Sapindus pericarp (SP) extraction residue.

\begin{tabular}{|c|c|}
\hline Properties $^{a, b}$ & Value \\
\hline \multicolumn{2}{|l|}{ Proximate analysis } \\
\hline Ash $(w t \%)$ & $1.62 \pm 0.02$ \\
\hline Volatile matter $(\mathrm{wt} \%)$ & $80.82 \pm 1.90$ \\
\hline Fixed carbon ${ }^{c}(w t \%)$ & 17.56 \\
\hline \multicolumn{2}{|l|}{ Ultimate analysis } \\
\hline Carbon (wt\%) & $42.59 \pm 8.60$ \\
\hline Hydrogen $(w t \%)$ & $5.86 \pm 1.17$ \\
\hline Oxygen (wt\%) & $37.30 \pm 0.15$ \\
\hline Nitrogen (wt\%) & $0.36 \pm 0.09$ \\
\hline Sulfur $(w t \%)$ & $0.11 \pm 0.02$ \\
\hline Calorific value (MJ / kg) & $20.97 \pm 1.89$ \\
\hline
\end{tabular}

${ }^{\mathrm{a}}$ On a dry basis. ${ }^{\mathrm{b}}$ The mean \pm standard deviation for two determinations. ${ }^{\mathrm{c}}$ By difference.

In order to investigate the thermal decomposition behavior of the SP sample, its thermogravimetric analysis (TGA) and derivative thermogravimetry (DTG) curves were obtained at two heating rates (i.e., 5 and $\left.10{ }^{\circ} \mathrm{C} / \mathrm{min}\right)$ by the flow rate of nitrogen $\left(50 \mathrm{~cm}^{3} / \mathrm{min}\right.$ ). As shown in Figure 1, these curves revealed similar thermal variations in the temperature range of $30-900{ }^{\circ} \mathrm{C}$. Taking the TGA/DTG curves at $5{ }^{\circ} \mathrm{C} / \mathrm{min}$ as an example, the first weight decline occurred in the temperature range of $50-180^{\circ} \mathrm{C}$, which should be attributed to the losses of moisture and the light volatile components. Thereafter, a significant weight loss was observed at the temperature range of $200-400{ }^{\circ} \mathrm{C}$, which can be divided into the decomposition of hemicellulose (major)/lignin (minor) $\left(200-320^{\circ} \mathrm{C}\right.$ ) and cellulose (major)/lignin (minor) $\left(320-400^{\circ} \mathrm{C}\right.$ ). Finally, the thermal loss of lignin was continuously progressed at above $400^{\circ} \mathrm{C}$. It was reported that the loss of lignin typically occurred in a wide temperature range from 180 to $900{ }^{\circ} \mathrm{C}$ [24]. In addition, volatilization losses of the inorganic minerals (e.g., metal carbonates/oxides/chlorides) may have appeared above $600{ }^{\circ} \mathrm{C}$ because some of these minerals have lower melting points, like potassium oxide $\left(740{ }^{\circ} \mathrm{C}\right)$ and calcium chloride $\left(772{ }^{\circ} \mathrm{C}\right)$. From the data in the TGA/DTG curves (Figure 1), the torrefaction experiments of the dried SP were performed in the temperature range of $200-320^{\circ} \mathrm{C}$ to produce the torrefied products in this work.

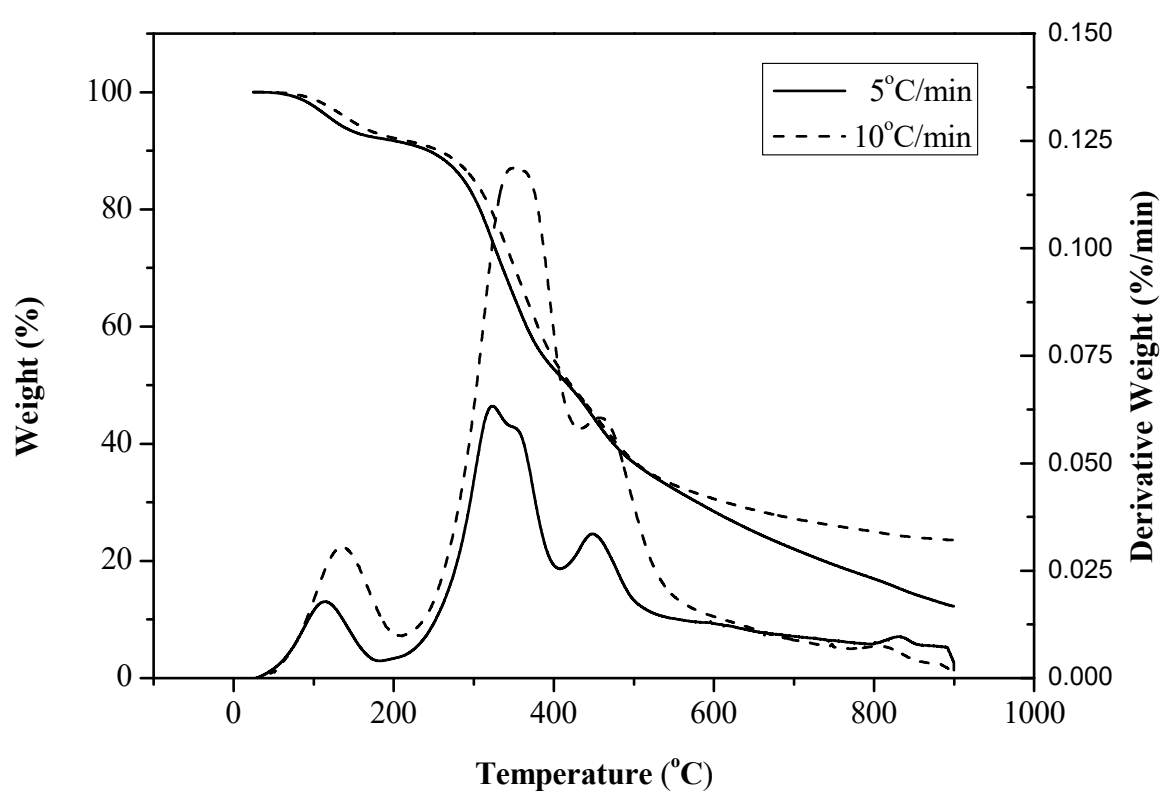

Figure 1. Thermogravimetric analysis/derivative thermogravimetry (TGA/DTG) curves of the Sapindus pericarp (SP) extraction residue at two heating rates $\left(5\right.$ and $\left.10^{\circ} \mathrm{C} / \mathrm{min}\right)$. 


\subsection{Fuel Properties of SP-Torrefied Products (T-SP)}

As mentioned in Section 2.3, the torrefaction experiments were designed by a matrix of the temperature (i.e., 200, 240, 280 and $320{ }^{\circ} \mathrm{C}$ ) and residence time (i.e., 0, 30 and $60 \mathrm{~min}$ ) and were also performed in duplicate. According to the statistical data on the mass yield (Table 2), it showed that the uncertainty analysis of the torrefaction experiment was not significant. As listed in Table 2, the mass yields of the SP-torrefied products indicated a decreasing trend with the torrefaction temperature and/or residence time increased. The results should be associated with more intense decomposition reactions of lignocellulosic constituents, which occurred at higher temperatures and/or longer residence times. More significantly, the maximal variations on the mass yields of the SP-torrefied products were seen to be in the range of $300-320^{\circ} \mathrm{C}$, which was in accordance with the TGA/DTG curves shown in Figure 1. For instance, the mass yields of the SPtorrefied products produced at various temperatures for holding 0 min were $91.1 \%\left(200{ }^{\circ} \mathrm{C}\right)$, $84.8 \%\left(240{ }^{\circ} \mathrm{C}\right), 74.3 \%\left(280^{\circ} \mathrm{C}\right)$ and $48.9 \%\left(320^{\circ} \mathrm{C}\right)$. Regarding the thermal decompositions of the lignocellulosic constituents, cellulose (a crystalline polysaccharide) and lignin (a highly branched, amorphous, three-dimensional polysaccharide) exhibited higher thermal stability than hemicellulose (an amorphous polysaccharide) [1], thus causing the latter to be the maximal decomposition, with the pyrolysis temperature ranging from 220 to $330^{\circ} \mathrm{C}[25,26]$. Although the larger mass yields of the SP-torrefied products were produced at lower temperatures and/or shorter residence times, their fuel properties were not useful for various applications of solid fuels.

Table 2. Mass yields and calorific values of SP-torrefied products (T-SP) as a function of the temperature $\left(200-360{ }^{\circ} \mathrm{C}\right)$ and residence time (0-60 $\mathrm{min})$.

\begin{tabular}{|c|c|c|c|c|}
\hline SP-Torrefied Product ${ }^{\text {a }}$ & $\begin{array}{l}\text { Mass Yield }{ }^{b} \\
\quad(w t \%)\end{array}$ & $\begin{array}{c}\text { Calorific Value }{ }^{b} \\
(\mathrm{MJ} / \mathrm{kg})\end{array}$ & $\begin{array}{c}\text { Enhancement Factor }{ }^{c} \\
(-)\end{array}$ & $\begin{array}{c}\text { Energy Yield }^{\mathrm{d}} \\
(\%)\end{array}$ \\
\hline T-SP-200-0 e & $91.09 \pm 0.08$ & $23.07 \pm 0.56$ & 1.10 & 100.18 \\
\hline T-SP-200-30 & $83.79 \pm 1.00$ & $23.78 \pm 0.76$ & 1.13 & 95.00 \\
\hline T-SP-200-60 & $83.00 \pm 1.65$ & $23.90 \pm 0.74$ & 1.14 & 94.59 \\
\hline T-SP-240-0 & $84.79 \pm 2.29$ & $23.54 \pm 0.08$ & 1.12 & 95.17 \\
\hline T-SP-240-30 & $75.57 \pm 2.83$ & $25.46 \pm 0.73$ & 1.21 & 91.72 \\
\hline T-SP-240-60 & $73.34 \pm 2.35$ & $25.37 \pm 0.54$ & 1.21 & 88.70 \\
\hline T-SP-280-0 & $74.31 \pm 2.95$ & $24.66 \pm 0.14$ & 1.18 & 87.37 \\
\hline T-SP-280-30 & $60.16 \pm 3.15$ & $28.60 \pm 0.60$ & 1.36 & 82.04 \\
\hline T-SP-280-60 & $55.60 \pm 3.27$ & $28.39 \pm 0.33$ & 1.35 & 75.27 \\
\hline T-SP-320-0 & $48.85 \pm 0.49$ & $28.32 \pm 0.23$ & 1.35 & 65.98 \\
\hline T-SP-320-30 & $45.06 \pm 2.27$ & $28.41 \pm 0.79$ & 1.35 & 61.03 \\
\hline T-SP-320-60 & $43.52 \pm 2.90$ & $27.97 \pm 0.34$ & 1.33 & 58.05 \\
\hline
\end{tabular}

${ }^{a}$ Dry basis. ${ }^{b}$ Means with standard deviations for two replications. ${ }^{c}$ The enhancement factor was obtained by a ratio of the calorific value for SP-torrefied products to the calorific value for SP (i.e., $20.97 \mathrm{MJ} / \mathrm{kg}$ ). ${ }^{\mathrm{d}}$ The energy yield was obtained by multiplication of the mass yield and the ratio of the calorific values for SP-torrefied products to the calorific value for SP (i.e., $20.97 \mathrm{MJ} / \mathrm{kg}$ ). ${ }^{\mathrm{e}}$ A SP-torrefied product (T-SP-200-0) was noted as being produced at the torrefaction temperature of $200{ }^{\circ} \mathrm{C}$ and residence time of $0 \mathrm{~min}$.

In order to find the maximal fuel properties of the SP-torrefied products, the calorific values were used as the most important fuel properties in this work. As listed in Table 2, the calorific values of the SP-torrefied products indicated correlations with various process conditions. According to the data in Table 2, Figure 2 was further plotted to indicate the variations of the calorific values under a wide range of torrefaction conditions. The calorific values of the SP-torrefied products also indicated an increasing trend with increasing temperatures from 200 to $320{ }^{\circ} \mathrm{C}$ and extending the residence time from 0 to $60 \mathrm{~min}$. Furthermore, the figures in Table 2 also showed that the enhancement factors of the SPtorrefied products increased from 1.10 to 1.36. Making a comparison with the calorific value (i.e., $20.97 \mathrm{MJ} / \mathrm{kg}$ ) of the feedstock SP, the maximal enhancement factor (i.e., 1.36) was found in the product T-SP-280-30. This result could be attributed to the densification of carbon and the volatilization loss of noncarbon elements (e.g., oxygen) at higher temperatures and/or 
longer residence times. As observed in the TGA/DTG curves at $5{ }^{\circ} \mathrm{C} / \mathrm{min}$ (Figure 1), the optimal torrefaction conditions could be attributed to the maximal decomposition of the hemicellulosic constituent at about $320^{\circ} \mathrm{C}$, thus making a significant mass loss due to more releases of organic volatiles (e.g., arabinoxylan, xyloglucan and $\beta$-glucan) [26]. Although the torrefaction conditions at around $320^{\circ} \mathrm{C}$ for holding 0 min may be preferable for producing the SP-torrefied product, its mass yield was just about $48.9 \%$. As listed in Table 2, the energy yield of the optimal SP-torrefied product (i.e., T-SP-320-60) was below $70 \%$. Using the data in Table 2, the torrefaction conditions at $280^{\circ} \mathrm{C}$ (residence time of $30 \mathrm{~min}$ ) could properly produce the SP-torrefied product (i.e., T-SP-280-30), which had a calorific value and energy yield of $28.60 \mathrm{MJ} / \mathrm{kg}$ and $82.04 \mathrm{wt} \%$, respectively. As compared to the previous reports $[20,21]$, the energy yields indicated in this work were close to those of the torrefied biomass derived from a water caltrop husk (WCH) and rice husk (RH) at the similar torrefaction conditions. For instance, the energy yields of the $\mathrm{WCH}$-torrefied products at the torrefaction temperatures of $200-320^{\circ} \mathrm{C}$ and the residence times of $0-60 \mathrm{~min}$ ranged from $99.3 \mathrm{wt} \%$ to $65.6 \mathrm{wt} \%$. It also showed the maximal enhancement factor of 1.45 at $320^{\circ} \mathrm{C}$ for a residence time of $60 \mathrm{~min}$. In brief, the torrefaction conditions at $320^{\circ} \mathrm{C}$ for holding 0 min may be optimal for producing a lignite-like $\mathrm{RH}$-torrefied product because of its high enhancement factor (1.39) and energy yield (90.4 wt\%).

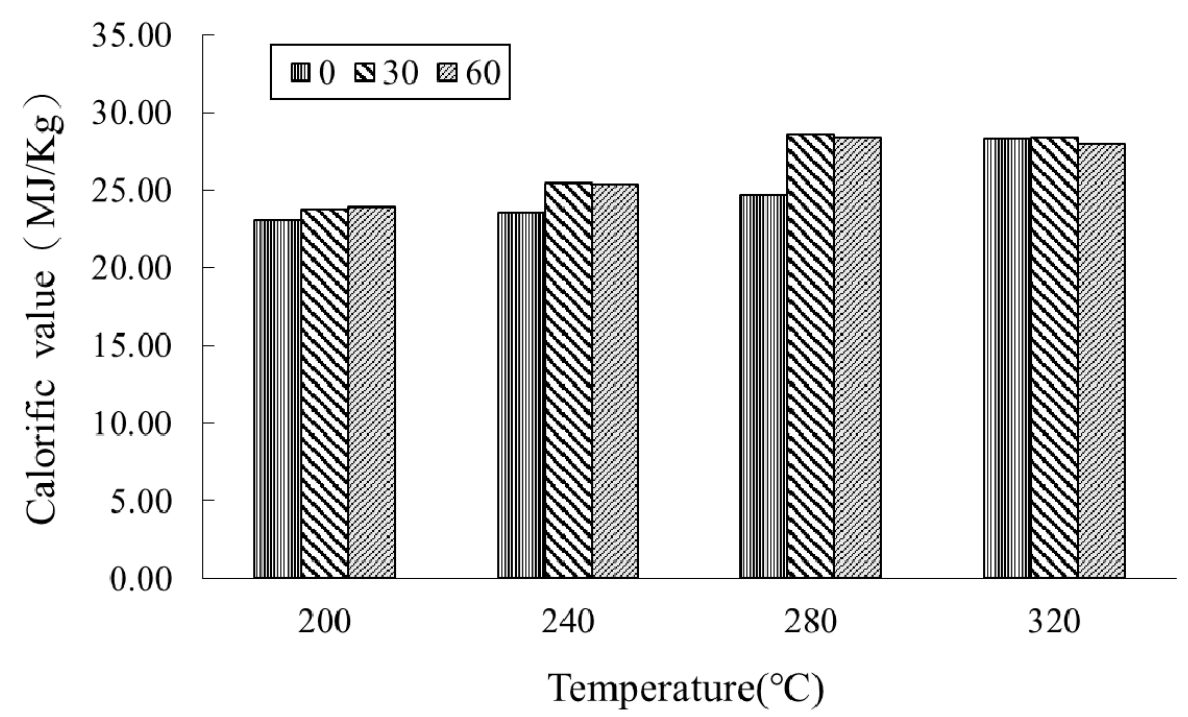

Figure 2. Variations on the calorific values of the SP-torrefied products as a function of the temperature $\left(200-360^{\circ} \mathrm{C}\right)$ and residence time $(0-60 \mathrm{~min})$.

Table 3 further lists the organic elemental values of the SP-torrefied products and their molar ratios of $\mathrm{H} / \mathrm{C}$ and $\mathrm{O} / \mathrm{C}$. The carbon contents ranged from $54.39 \mathrm{wt} \%$ to $70.33 \mathrm{wt} \%$ as a function of the torrefaction temperature $\left(200-320^{\circ} \mathrm{C}\right)$ and residence time $(0-60 \mathrm{~min})$. Obviously, the carbon was continuously increased with the increasing torrefaction temperatures from 240 to $320^{\circ} \mathrm{C}$ at residence times of 0 and $30 \mathrm{~min}$, but they subsequently decreased at $320^{\circ} \mathrm{C}$ for longer residence times (from $30 \mathrm{~min}$ to $60 \mathrm{~min}$ ). Although the maximal calorific value was $28.60 \mathrm{MJ} / \mathrm{kg}$ for SP-T-280-30, the maximal content of carbon (i.e., $70.33 \mathrm{wt} \%$ ) was observed at around $320^{\circ} \mathrm{C}$ for holding $30 \mathrm{~min}$. By contrast, the contents of hydrogen, oxygen and sulfur for the SP-torrefied products indicated a decreasing trend due to the volatilization losses of the noncarbon elements in the lignocellulosic compositions at more intense torrefaction conditions. This result was consistent with the variations on the mass yields and calorific values of the SP-torrefied products, as listed in Table 2. In review of the nitrogen content of the feedstock SP $(0.36 \%)$, the SP-torrefied products contained higher nitrogen contents, ranging from $0.78 \%$ to $1.86 \%$. In this regard, the emissions of nitrogen oxides (NOx) could cause potential air pollution when using the SP-torrefied product as a solid biofuel in a cofiring or combustion system. From the data on the organic elements in 
Table 3, the calorific values of the SP-torrefied products can be further estimated by using the commonly used equations like Dulong's formula [27]. It can be found that the calorific values were closely equal to those determined by the calorimeter instrument (Table 2).

Table 3. Organic elements of Sapindus pericarp (SP) and its torrefied products produced at different torrefaction temperatures $\left(200-320^{\circ} \mathrm{C}\right)$ and residence times $(0-60 \mathrm{~min})$.

\begin{tabular}{|c|c|c|c|c|c|c|c|}
\hline \multirow{2}{*}{$\begin{array}{l}\text { Sapindus Pericarp (SP) and Its } \\
\text { Torrefied Products (SP-T) }\end{array}$} & \multicolumn{5}{|c|}{ Organic Elements (wt\%) } & \multirow{2}{*}{$\mathrm{H} / \mathrm{C}^{\mathrm{a}}$} & \multirow{2}{*}{$\mathrm{O} / \mathrm{C}^{\mathrm{a}}$} \\
\hline & $\mathrm{C}$ & $\mathbf{H}$ & $\mathbf{N}$ & $\mathbf{O}$ & $S$ & & \\
\hline SP & $42.59 \pm 8.60$ & $5.86 \pm 1.17$ & $0.36 \pm 0.09$ & $37.30 \pm 0.15$ & $0.11 \pm 0.02$ & 1.65 & 0.66 \\
\hline T-SP-200-0 e & $54.39 \pm 0.54$ & $6.72 \pm 0.12$ & $1.68 \pm 0.13$ & $41.62 \pm 0.78$ & $0.38 \pm 0.13$ & 1.48 & 0.57 \\
\hline T-SP-200-30 & $57.84 \pm 1.99$ & $6.76 \pm 0.05$ & $1.53 \pm 0.23$ & $38.55 \pm 0.12$ & $0.24 \pm 0.03$ & 1.40 & 0.50 \\
\hline T-SP-200-60 & $58.62 \pm 3.01$ & $6.53 \pm 0.25$ & $1.63 \pm 0.01$ & $35.36 \pm 0.85$ & $0.23 \pm 0.05$ & 1.34 & 0.45 \\
\hline T-SP-240-0 & $54.92 \pm 1.97$ & $6.70 \pm 0.22$ & $1.29 \pm 0.41$ & $38.30 \pm 3.90$ & $0.15 \pm 0.01$ & 1.46 & 0.52 \\
\hline T-SP-240-30 & $58.66 \pm 0.18$ & $6.24 \pm 0.05$ & $1.36 \pm 0.08$ & $34.20 \pm 1.27$ & $0.15 \pm 0.01$ & 1.28 & 0.44 \\
\hline T-SP-240-60 & $61.76 \pm 1.20$ & $6.19 \pm 0.10$ & $1.50 \pm 0.06$ & $33.57 \pm 0.70$ & $0.14 \pm 0.00$ & 1.20 & 0.41 \\
\hline T-SP-280-0 & $57.50 \pm 1.85$ & $6.11 \pm 0.16$ & $0.78 \pm 0.01$ & $37.47 \pm 3.06$ & $0.12 \pm 0.00$ & 1.28 & 0.49 \\
\hline T-SP-280-30 & $67.05 \pm 0.71$ & $5.69 \pm 0.14$ & $1.76 \pm 0.16$ & $25.41 \pm 0.43$ & $0.14 \pm 0.01$ & 1.02 & 0.28 \\
\hline T-SP-280-60 & $68.59 \pm 1.28$ & $5.24 \pm 00.34$ & $1.86 \pm 0.01$ & $25.78 \pm 1.22$ & $0.14 \pm 0.00$ & 0.92 & 0.28 \\
\hline T-SP-320-0 & $69.72 \pm 0.94$ & $5.08 \pm 0.22$ & $1.26 \pm 0.10$ & $24.32 \pm 0.66$ & $0.12 \pm 0.01$ & 0.87 & 0.26 \\
\hline T-SP-320-30 & $70.33 \pm 0.39$ & $4.17 \pm 0.02$ & $1.19 \pm 0.11$ & $24.37 \pm 0.03$ & $0.11 \pm 0.01$ & 0.71 & 0.26 \\
\hline T-SP-320-60 & $68.77 \pm 3.44$ & $3.94 \pm 0.57$ & $1.59 \pm 0.25$ & $25.05 \pm 0.19$ & $0.14 \pm 0.01$ & 0.69 & 0.27 \\
\hline
\end{tabular}

${ }^{a}$ Molecular ratio, ${ }^{\text {e }}$ A SP-torrefied product (T-SP-200-0) was noted as being produced at the torrefaction temperature of $200{ }^{\circ} \mathrm{C}$ and residence time of $0 \mathrm{~min}$.

In order to evaluate the ranks of the SP-torrefied products in comparison with fossil fuels (i.e., coal) [1], a van Krevelen diagram (Figure 3) was plotted by using the data on the molecular ratios of $\mathrm{O} / \mathrm{C}$ and $\mathrm{H} / \mathrm{C}$, as seen in Table 3. Obviously, the values of molar $\mathrm{H} / \mathrm{C}$ and $\mathrm{O} / \mathrm{C}$ will be reduced at higher torrefaction temperatures and/or longer residence times. As shown in Table 2, the contents of $\mathrm{H}$ and $\mathrm{O}$ were decreased with the increase in the torrefaction temperature and/or residence time. This result was attributable to the volatiles formed, which contained components containing $\mathrm{O}$ and $\mathrm{H}$ such as water, acids and alcohols. For example, the values of the molar $\mathrm{H} / \mathrm{C}$ and $\mathrm{O} / \mathrm{C}$ decreased from 1.65 and 0.66 for the T-SP-200-0 to 0.69 and 0.27 for the T-SP-320-60. Based on the values of molar H/C and O/C (i.e., 1.02 and 0.28 , respectively), the optimal SP-torrefied product (i.e., T-SP-280-30) should belong to the class of lignite [1]. The results were in accordance with those reported previously $[20,21,28]$ and recently reviewed [4-9]. In addition, the feedstock SP has the highest values of atomic $\mathrm{O} / \mathrm{C}$ and $\mathrm{H} / \mathrm{C}$ (Table 3), making it difficult to transform the biomass into liquid fuels. In general, a high oxygen contained in the biomass will consume a part of the hydrogen in the biomass during the thermochemical process (e.g., torrefaction) due to the production of less beneficial water.

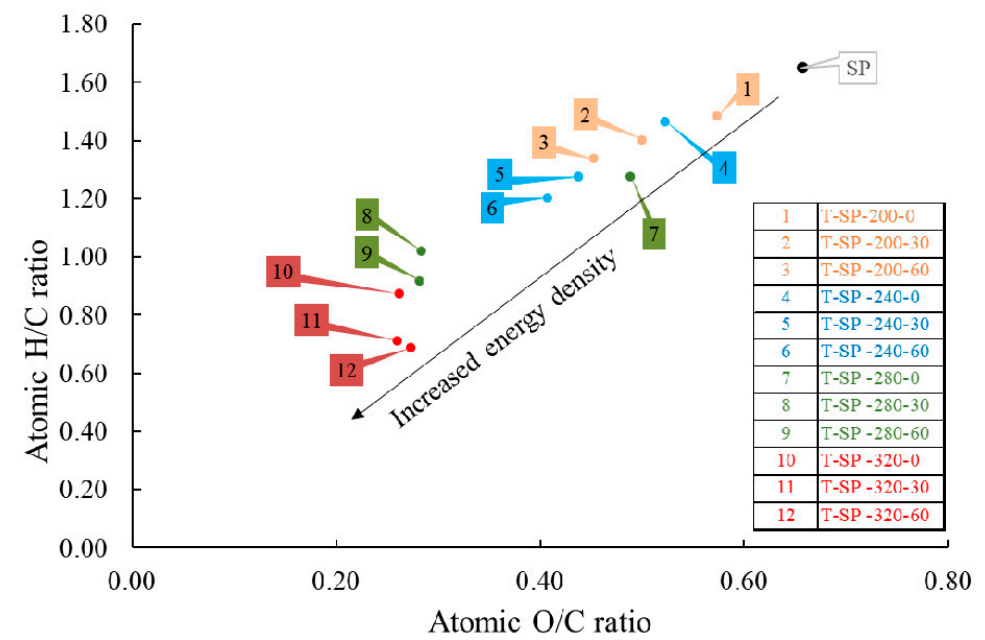

Figure 3. van Krevelen diagram of the SP-torrefied products. 
Based on the EDS analysis (Figure 4), the elemental compositions were observed on the surfaces of the feedstock SP and optimal SP-torrefied product (i.e., T-SP-280-30). It showed that the major elements included carbon $(\mathrm{C})$, oxygen $(\mathrm{O})$, potassium $(\mathrm{K})$ and calcium $(\mathrm{Ca})$. Obviously, the metal elements in the SP-torrefied product should be derived from the precursor SP. These inorganic elements could be presented in the forms of carbonates, oxides or chlorides, possibly leading to serious slagging, fouling or corrosion in boilers or gasifiers when cofiring a SP-torrefied product with pulverized coal [29].

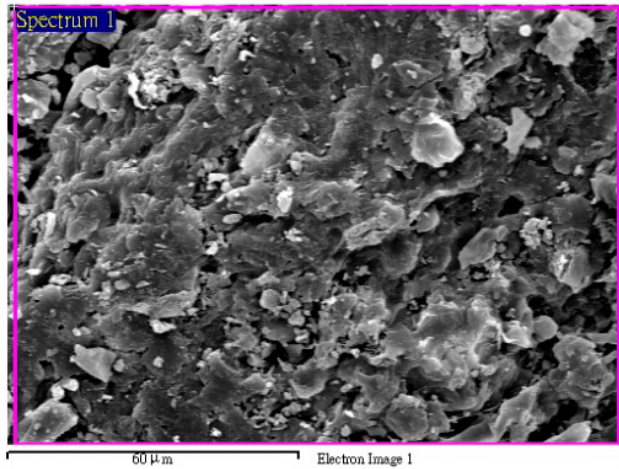

Electron Image 1

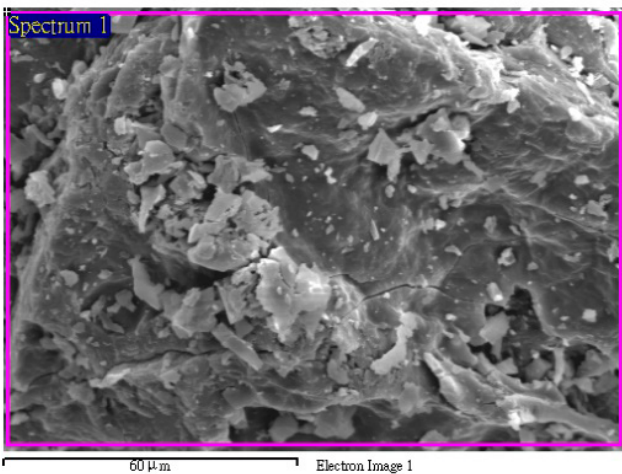

Flectron Image 1

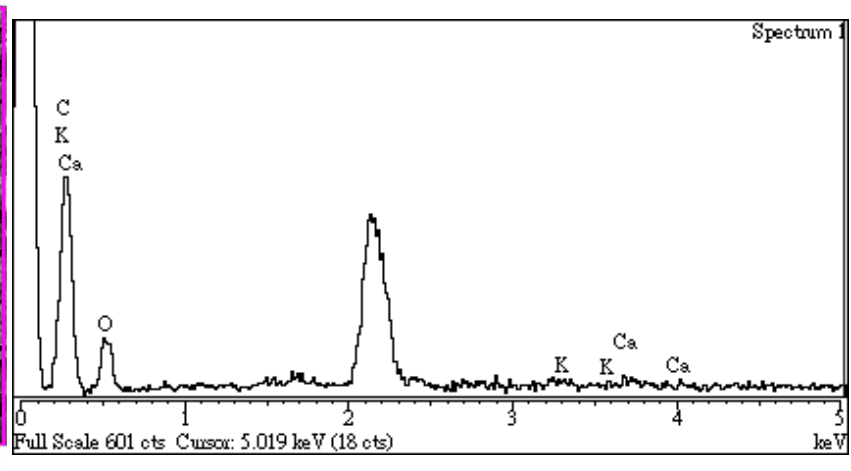

(a)

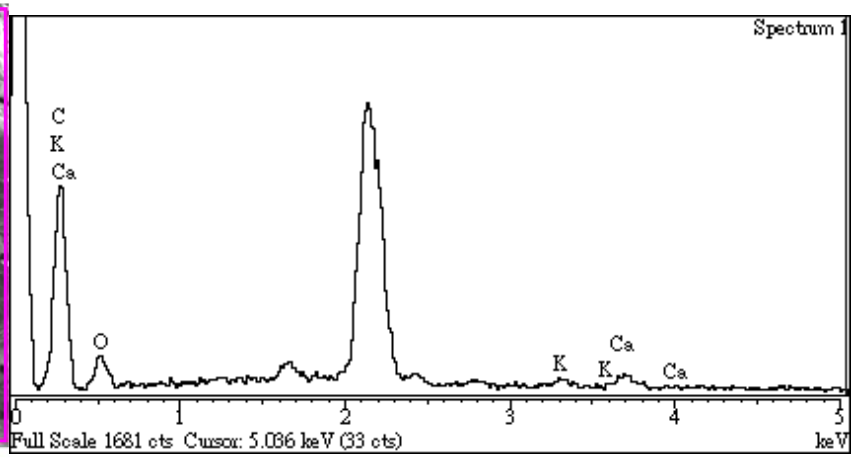

(b)

Figure 4. SEM/EDS analyses of (a) a feedstock SP and (b) optimal SP-torrefied product (T-SP-280-30).

\section{Conclusions}

In this work, Sapindus pericarp (SP), a novel extraction residue from the local soapberrybased products manufacturing factory (Tainan City, Taiwan), was pretreated by the torrefaction method for improving its fuel properties. In order to find the optimal process conditions, a dried SP was performed under various temperatures $\left(200-320^{\circ} \mathrm{C}\right)$ and residence times (i.e., 0-60 $\mathrm{min}$ ). The data from the thermogravimetric analysis (TGA) showed that the weight loss of hemicellulose in the SP biomass was observed in the temperature range of $200-320^{\circ} \mathrm{C}$, thus adopting the data in the torrefaction experiments. Based on the results of the mass yields and calorific values of the SP-torrefied products, it was found that the optimal conditions at around $280^{\circ} \mathrm{C}$ for holding $30 \mathrm{~min}$ would be preferred for the production of the SP-torrefied product with the highest calorific value (i.e., $28.60 \mathrm{MJ} / \mathrm{kg}$ ), which increased by $36 \%$ in comparison with that of its feedstock SP (i.e., $20.97 \mathrm{MJ} / \mathrm{kg}$ ). The contents of carbon and hydrogen in the optimal SP-torrefied product presented up to $67.05 \mathrm{wt} \%$ and $5.69 \mathrm{wt} \%$, respectively. On the other hand, the energy yields of the SPtorrefied products and their values of molar $\mathrm{H} / \mathrm{C}$ and $\mathrm{O} / \mathrm{C}$ showed a decreasing trend with increasing the torrefaction temperature and/or extending the residence time. By plotting all the SP-torrefied products in a van Krevelen diagram, some torrefied products could be grouped into fuel properties of lignite-like fuels. However, the SP-torrefied fuels would 
be particularly susceptible to the problems of slagging and fouling due to relatively high contents of potassium $(\mathrm{K})$ and calcium $(\mathrm{Ca})$ when used $\mathrm{t}$ as a solid fuel directly in boilers.

Author Contributions: Conceptualization, W.-T.T.; methodology, X.Z., K.-S.Y. and C.-H.T.; validation, T.-J.J.; formal analysis, T.-J.J.; data curation, Y.-Q.L.; writing-original draft preparation, W.-T.T.; writing-review and editing, W.-T.T.; visualization, T.-J.J. and Y.-Q.L. and supervision, W.-T.T. All authors have read and agreed to the published version of the manuscript.

Funding: This research received no external funding.

Institutional Review Board Statement: Not applicable.

Informed Consent Statement: Not applicable.

Data Availability Statement: The data is contained within the article.

Acknowledgments: Sincere appreciation is expressed to acknowledge the National Pingtung University of Science and Technology for their assistance in the scanning electron microscopy (SEM) and energy-dispersive X-ray spectroscopy (EDS) analyses.

Conflicts of Interest: The authors declare no conflict of interest.

\section{References}

1. Basu, P. Biomass Gasification, Pyrolysis and Torrefaction, 2nd ed.; Academic Press: London, UK, 2013; pp. 87-145.

2. Li, H.; Liu, X.; Legros, R.; Bi, X.T.; Lim, C.J.; Sokhansan, S. Torrefaction of sawdust in a fluidized bed reactor. Bioresour. Technol. 2012, 103, 453-458. [CrossRef]

3. van der Stelt, M.J.C.; Gerhauser, H.; Kiel, J.H.A.; Ptasinski, K.J. Biomass upgrading by torrefaction for the production of biofuels: A review. Biomass Bioenergy 2011, 35, 3748-3762. [CrossRef]

4. Niu, Y.; Lv, Y.; Lei, Y.; Liu, S.; Liang, Y.; Wang, D.; Hui, S. Biomass torrefaction: Properties, applications, challenges, and economy. Renew. Sustain. Energy Rev. 2019, 115, 109395. [CrossRef]

5. Negi, S.; Jaswal, G.; Dass, K.; Mazumder, K.; Elumalai, S.; Roy, J.K. Torrefaction: A sustainable method for transforming of agri-wastes to high energy density solids (biocoal). Rev. Environ. Sci. Biotechnol. 2020, 19, 463-488. [CrossRef]

6. Olugbade, T.O.; Ojo, O.T. Biomass torrefaction for the production of high-grade solid biofuels: A review. Bioenergy Res. 2020, 13, 999-1015. [CrossRef]

7. $\quad$ Chen, W.H.; Lin, B.J.; Lin, Y.Y.; Chu, Y.S.; Ubando, A.T.; Show, P.L.; Ong, H.C.; Chang, J.S.; Ho, S.H.; Culaba, A.B.; et al. Progress in biomass torrefaction: Principles, applications and challenges. Prog. Energy Combust. Sci. 2021, 82, 100887. [CrossRef]

8. Knapczyk, A.; Francik, S.; Jewiarz, M.; Zawi'slak, A.; Francik, R. Thermal treatment of biomass: A bibliometric analysis-The torrefaction case. Energies 2021, 14, 162. [CrossRef]

9. Sarker, T.R.; Nanda, S.; Dalai, A.K.; Meda, V. A review of torrefaction technology for upgrading lignocellulosic biomass to solid biofuels. Bioenergy Res. 2021, 14, 645-669. [CrossRef]

10. Dobhal, U.; Bisht, N.S.; Bhandari, S.L. Traditional values of Sapindus mukorossi gaertn. vern. Ritha: A review. Plant. Arch. 2007, 7, 485-486.

11. Liu, M.; Chen, Y.L.; Kuo, Y.H.; Lu, M.K.; Liao, C.H. Aqueous extract of Sapindus mukorossi induced cell death of A549 cells and exhibited antitumor property in vivo. Sci. Rep. 2018, 8, 4831. [CrossRef]

12. Xu, Y.Y.; Gao, Y.; Chen, Z.; Zhao, G.C.; Liu, J.M.; Wang, X.; Gao, S.L.; Zhang, D.G.; Jia, L.M. Metabolomics analysis of the soapberry (Sapindus mukorossi Gaertn.) pericarp during fruit development and ripening based on UHPLC-HRMS. Sci. Rep. 2021, 11, 11657. [CrossRef] [PubMed]

13. Ma, S.J.; Fu, L.L.; He, S.Q.; Lu, X.P.; Wu, Y.Y.; Ma, Z.Q.; Zhang, X. Potent herbicidal activity of Sapindus mukorossi Gaertn. against Avena fatua L. and Amaranthus retroflexus L. Ind. Crops Prod. 2018, 122, 1-6. [CrossRef]

14. Dai, Z.Y.; Wang, J.; Ma, X.J.; Sun, J.; Tang, F. Laboratory and field evaluation of the phytotoxic activity of Sapindus mukorossi Gaertn pulp extract and identification of a phytotoxic substance. Molecules 2021, 26, 1318. [CrossRef]

15. Gonzalez, P.J.; Sorensen, P.M. Characterization of saponin foam from Saponaria officinalis for food applications. Food Hydrocoll. 2020, 101, 105541. [CrossRef]

16. Rai, S.; Acharya, E.; Kafle, A.; Devkota, H.P.; Bhattarai, A. Plant-derived saponins: A review of their surfactant properties and applications. Preprints 2021, 2021080152. [CrossRef]

17. Zhang, C.; Ho, S.H.; Chen, W.H.; Fu, Y.; Chang, J.S.; Bi, X. Oxidative torrefaction of biomass nutshells: Evaluations of energy efficiency as well as biochar transportation and storage. Appl. Energy 2019, 235, 428-441. [CrossRef]

18. Velusamy, K.; Periyasamy, S.; Kumar, P.S.; Jayaraj, T.; Krishnasamy, R.; Sindhu, J.; Sneka, D.; Subhashini, B.; Vo, D.V.N. Analysis on the removal of emerging contaminant from aqueous solution using biochar derived from soap nut seeds. Environ. Pollut. 2021, 287, 117632. [CrossRef] [PubMed]

19. Tsai, W.T.; Huang, P.C. Characterization of acid-leaching cocoa pod husk (CPH) and its resulting activated carbon. Biomass Convers. Biorefin. 2018, 8, 521-528. [CrossRef] 
20. Tsai, W.T.; Lin, Y.Q.; Tsai, C.H.; Chung, M.H.; Chu, M.H.; Huang, H.J.; Jao, Y.H.; Yeh, S.I. Conversion of water caltrop husk into biochar by torrefaction. Energy 2020, 195, 116967. [CrossRef]

21. Tsai, W.T.; Jiang, T.J.; Tang, M.S.; Chang, C.H.; Kuo, T.H. Enhancement of thermochemical properties on rice husk under a wide range of torrefaction conditions. Biomass Convers. Biorefin. 2021, in press. [CrossRef]

22. Tiwari, D.P.; Sharma, D.N.; Raunija, T.S.K. Sapindus based activated carbon by chemical activation. Res. J. Mater. Sci. 2013, 1, 9-15.

23. Jenkins, B.M.; Baxter, L.L.; Miles, T.R., Jr.; Miles, T.R. Combustion properties of biomass. Fuel Process. Technol. 1998, 54, 17-46. [CrossRef]

24. Mosek, O.; Johnston, C.T. Thermal Analysis for Biochar Characterisation. In Biochar: A Guide to Analytical Methods; Singh, B., Camps-Arbestain, M., Lehmann, J., Eds.; CRC Press: Boca Raton, FL, USA, 2017; pp. 283-293.

25. Yang, H.; Yan, R.; Chen, H.; Lee, D.H.; Zheng, C. Characteristics of hemicellulose, cellulose and lignin pyrolysis. Fuel 2007, 86, 1781-1788. [CrossRef]

26. Werner, K.; Pommer, L.; Brostrom, M. Thermal decomposition of hemicelluloses. J. Anal. Appl. Pyrolysis 2014, 110, 130-137. [CrossRef]

27. Hosokai, S.; Matsuoka, K.; Kuramoto, K.; Suzuki, Y. Modification of Dulong's formula to estimate heating value of gas, liquid and solid fuels. Fuel Process. Technol. 2016, 152, 399-405. [CrossRef]

28. Tsai, C.H.; Tsai, W.T.; Liu, S.C.; Lin, Y.Q. Thermochemical characterization of biochar from cocoa pod husk prepared at low pyrolysis temperature. Biomass Conver. Biorefin. 2018, 8, 237-243. [CrossRef]

29. Lachman, J.; Balas, M.; Lisy, M.; Lisa, H.; Milcak, P.; Elbl, P. An overview of slagging and fouling indicators and their applicability to biomass fuels. Fuel Process. Technol. 2021, 217, 106804. [CrossRef] 